\title{
ПРОГНОСТИЧНИЙ ІНДЕКС ВІДНОВЛЕННЯ СВІДОМОСТІ У ПАЦІЕНТІВ ІЗ ТРИВАЛИМИ ІІІ РОЗЛАДАМИ ПІСЛЯ ТЯЖКОї ЧЕРЕПНО-МОЗКОВОї ТРАВМИ
}

\begin{abstract}
Резюме. В основу роботи покладено результати діагностики, реабілітації та відновного лікування 220-ти хворих із посткоматозними тривалими розладами свідомості після тяжкої черепно-мозкової травми (ЧМТ). Головну увагу приділяють актуальній темі прогнозування відновлення свідомості відповідно до стадій класифікації Т. А. Доброхотової у ході реабілітаційного маршруту. Розкрито особливості 28-ми ключових зведених високоінсоормативних показників, які використовували для розрахунку прогностичного індексу відновлення свідомості, проведено аналіз маловивчених та спірних донині питань щодо їх кореляції із клінічними показниками переходу від вегетативного статусу до вищих стадій синдромів посткоматозної свідомості. В дослідженні акцентується на тому, що прогностичний індекс відновлення свідомості виконував практичну і визначальну срункцію, а не був лише умовою в плануванні тактики подальших реабілітаційних заходів та визначенні їх вірогідної ефрективності. На основі отриманих даних зробили висновок про суттєву перевагу нейрофрізіологічних методів діагностики (кількісної ЕЕГ) над нейровізуалізуючими (СКТ, МРТ) в прогнозуванні відновлення свідомості після тривалої посттравматичної коми. Найінсрормативнішою та найчутливішою виявилися група показників нелінійної нейродинаміки та детермінованого хаосу: ентропія, розмірності атракторів, мультифрактальні властивості сигналів ЕЕГ, а також показників кореляційного та спектрального аналізу. Саме ці показники і їх значення утворювали 16 з 28 специфрічних індексованих величин, одночасна наявність чи відсутність яких у конкретного хворого на конкретній стадії відновлення свідомості фрормувала ядро їх прогностичного індексу відновлення, а динаміка змін у часі доклінічно свідчила за напрямок еволюції біоелектричної активності головного мозку, а тому й еквівалентних коркових фрункцій. Усі інші методи проведеної діагностики були допоміжними і тільки посилювали або послаблювали ймовірний прогноз.
\end{abstract}

Ключові слова: кількісна електроенцефалографрія; черепно-мозкова травма; посткоматозні порушення свідомості; нелінійний аналіз ЕЕГ; атрактор; динамічна система; ентропія, детермінований хаос; інформаційна розмірність; прогностичний індекс відновлення свідомості.

Вступ Постійно зростаючі частота та поширеність нейротравми в світі давно вже має характер "епідемії" $[12,13]$. Об'єктивні досягнення в медицині за останнє десятиріччя, які стосуються перш за все реанімації, інтенсивної терапії, нейрохірургії привели до зростання кількості тих, хто вижив, навіть із вкрай тяжкими клінічними фрормами черепно-мозкової травми [3]. Однак разом з цим, закономірно зросла кількість хворих із посттравматичними посткоматозними тривалими розладами свідомості $[4,20]$. А у тих випадках, де вдалося за короткі терміни відновити рівень ясної свідомості чи перехідних синдромів ії порушення (високий рівень свідомості за Т. А. Доброхотовою $[7,8])$, досить часто діагностують різні за поєднанням, типом і складністю когнітивно-мовленнєві, рухові, чутливі розлади, що фрормують стійку інвалідизацію цих пацієнтів [19].

Як свідчать численні наукові дослідження [10, 17, 21], через певні обмеження (вік більше 39-40 років, високий ступінь структурних ушкоджень головного мозку, виразні фрункціональні зміни церебрального кровотоку чи/та лабораторних специфічних показників, період травматичної хвороби) далеко не кожен хворий із черепно-мозковою травмою (ЧМТ) після тяжкої ЧМТ може претендувати на високі показники відновлення свідомості після порушених фрункцій та дієздатності. Проте все частіше трапляються повідомлення, в яких акцентують увагу на тому, що всупереч наявності у пацієнтів вищевказаних доведених несприятливих прогностичних фракторів, диференційоване залучення комплексу передових технологій та методик ранньої нейрореабілітації завершувалося успішним клінічним доказовим результатом $[7,12,18]$.

Тому не дивно, що нині такої актуальності набули питання прогнозування виходу тяжкої ЧМТ у світлі можливостей діагностики, відновного лікування та реабілітації, інтерес до яких дедалі тільки зростає $[2,5,11]$.

На даний час існує багато різних алгоритмів та моде- лей $[1,2,9]$, за якими пропонують визначати можливий прогноз травмованих і відповідно до цього обґрунтовувати економічно-організаційні аспекти медичної допомоги та обирати чи планувати тактику усіх подальших дій. Але незважаючи на висвітлені різноманітні аргументи та оприлюднені приклади з практики $[6,11]$, детальні пояснення та усесторонній аналіз даних, які свідчать на користь зазначених тих чи інших концепцій та ідей, поки єдиного підходу щодо прогнозування виходу 3 тяжкої ЧМТ, де мають місце тривалі розлади свідомості, і який би в більшості клінічних випадків зберігав високу достовірність й прикладну ефективність, на жаль, не вироблено [14]. Більше того, практична відтворюваність найпоширеніших 3 них виявляється згодом сумнівною [5, 15], а закладені в основу розрахунків математичні закони часто $€$ не зрозумілими чи, наприклад лінійними, що не можуть взагалі застосовуватися для подібних дослідницьких завдань непараметричного характеру [16].

Все це наштовхує на потребу продовжувати досліджувати дану широко відкриту і все ж маловивчену тему, та спрямовувати науковий пошук на розробку більш простих, універсальних і разом з тим, інформативних прогностичних інструментів для оцінки вірогідності відновлення ясного рівня свідомості в посткоматозному періоді тяжкої ЧМТ.

Метою дослідження було розрахувати прогностичний індекс відновлення свідомості та на його основі розробити модель прогнозування переходу від вегетативного статусу до вищих стадій синдромів посткоматозної свідомості за класифрікацією Т. А. Доброхотової в ході реабілітації та відновного лікування, визначити інформативність та чутливість даного показника, з'ясувати практичну доцільність його використання.

МАТЕРІАЛИ І МЕТОДИ В осНовУ роботИ покЛаДено аналіз 220-ти хворих із травматичними посткоматозними розладами свідомості, яких обстежували, і проходили 
курси нейрореабілітаційного (НР) лікування в ДУ “Інститут нейрохірургії імені акад. А. П. Ромоданова НАМН України" та в ТОВ "Науково-практичний центр нейрореабілітації "Модус" з січня 2007 р. до липня 2018 р. включно.

Комп'ютерні електроенцефалографрічні (КЕЕГ) дослідження виконували усім хворим без винятку (100\%, $\mathrm{N}=220)$ при визначенні контрольних точок реабілітаційного маршруту, а також під час окремих занять, таких, як наприклад вертикалізаційні заняття, чи спеціалізованих процедур зорової та слухової стимуляції головного мозку. Проте у випадках, коли пацієнт достроково досягав того чи іншого рівня посткоматозного синдрому відновлення свідомості, або "зависав" на якомусь етапі більше, а ніж прогнозувалося, виникала необхідність додаткових ЕЕГ-обстежень. Найчастіше $(36,8$ \%, n=81) для цього використовували холтер-ЕЕГ-моніторинг протягом 24 год.

Усього виконано 896 КЕЕГ, що складає в середньому 4 дослідження на одного хворого. 91,3 \% ( $=201 ; \mathrm{N}=220)$ досліджуваних були правшами (11 - яких переучили на правшів), а 18,7 \% (n=19; $\mathrm{N}=220)$ - лівшами.

У кожному випадку рутинну КЕЕГ доповнювали кількісним лінійним та нелінійним методами аналізу. Нелінійний багаторозмірний аналіз включав визначення величин ентропії, розмірності динамічних систем (складність), параметрів атракторів, а також мультифррактальних властивостей ЕЕГ.

Сценарій усієї сесії аналізували цілісно. Інтегральні індекси відтворюваності, як це було у випадку кількісних лінійних показників для нелінійних показників ЕЕГ, через принципово інший підхід до аналізу нейродинаміки не визначали, натомість застосовуючи умови "вирішального правила" [8], вдалося виявити клінічно значимі багаторозмірні властивості кількісної ЕЕГ, які значно посилили інформативність КЕЕГ в динаміці відновлення свідомості досліджуваних хворих та лягли в основу прогнозування.

Топограсрію і виразність ушкодження мозку визначали на основі методів нейровізуалізації КТ і МРТ при надходженні пацієнтів на відновне лікування та реабілітацію, а також в динаміці. В усіх хворих неодноразово виконано лабораторні біохімічні дослідження, проведено консультації суміжних спеціалістів.

Відповідно до попередніх робіт автора [10], де було встановлено, що у досліджуваних хворих рівень посткоматозного порушення свідомості жодним чином не корелював з виявленою семіотикою, а прогноз виходу на вищі рівні відновлення свідомості, починаючи з вегетативного статусу в межах першого року з моменту тяжкої ЧМТ ніяк не залежав від тривалості конкретної стадії та виразності неврологічних проявів травматичної хвороби, показники клініко-неврологічного обстеження до розрахунку прогностичного індексу відновлення свідомості не застосовували. За тією ж причиною не використовували дані кінезіологічного обстеження цих хворих.

Тому прогностичний (інтегральний) індекс відновлення (ПІВС) свідомості після тривалої постравматичної коми був розроблений лише на основі результатів нейровізуалізаційного, нейрофізіологічного обстеження та анамнестичних даних пацієнтів основної групи дослідження з використанням індексного методу [9]. Цей метод встановлення зв'язків між кількісно-якісними значеннями показників та станом свідомості включав статистично підтверджені, найінфрормативніші показники, з високою чутливістю (не менше 85 \%) та специсічністю (не менше 88 \%), які виявлені під час вищезазначеної діагностики.
Статистичну обробку отриманих даних проводили 3 використанням пакета прикладних програм "Statistica 6", пакета комп'ютерного аналізу "OfficeExcel 2016", вибіркового методу: вибіркової середньої, похибки середньої; для визначення вірогідності різниці між групами - непараметричні метод: $\mathrm{X}^{2-к р и т е р і и ̆ ~ д л я ~ п о р і в н я н н я ~ я к і с н и х ~}$ показників та t-критерій для порівняння кількісних параметрів; для порівняння двох незалежних груп - метод Манна-Уїтні.

РЕЗУЛЬТАТИ ДОСЛІДЖЕНЬ ТА ЇХ ОБГОВОРЕННЯ

Серед інсрормативних показників визначили ті, які мали високі значення інформативності, однак їх величини в даній дослідній групі не переходили через вищевказаний числовий бар'єр, тому з метою максимальної об'єктивізації такі показники в подальшому не визначали. Не виключено, що в іншій дослідній групі вони могли бути віднесені до розрахунку інтегрального прогностичного індексу відновлення. Типовим прикладом таких показників були період мовчання та міжпороговий індекс, розрахунок яких виконували під час дослідження моторних викликаних потенціалів. Хоча, в ході динамічних обстежень пацієнтів на різних стадіях відновлення свідомості на фоні застосування лікувальної транскраніальної ритмічної стимуляції відмічали покращення значень цих показників, проте їх кореляційний коефріцієнт в парі (величина-рівень свідомості) не перевищував середні значення критерію Пірсона, через це ними не нехтували в описі динаміки змін НФ показників, але в розробку прогностичного індексу не брали.

Необхідно зауважити, що відібрані показники володіли високою кореляцією з клінічними проявами для кожної зі стадій відновлення свідомості, а також були відтворюваними серед пацієнтів своєї групи (з аналогічним рівнем свідомості), що підтверджувало їх достеменність.

Оскільки ПІВС - аналітичний, базисний (досліджували різні періоди, однак база порівняння була однією і тією ж) та відносний показник, що характеризує зміну рівня свідомості в часі порівняно з початковим станом свідомості, а в даному випадку з вегетативним статусом, його прогнозуючі можливості додатково перевірено на групі контролю, де були виділені аналогічні інформативні значення.

У таблиці 1 наведено відібрані високоінформативні показники, на базі яких було розраховано прогностичний індекс відновлення свідомості після тривалої церебральної травматичної коми. Одні з цих показників були властиві тільки для випадків, коли відмічалося покращення рівня свідомості відповідно до стадій за Т. А. Доброхотовою (1985), а інші - тільки для випадків, які упродовж року залишалися в персистуючому вегетативному стані.

Оскільки усі ці показники є рівноцінно значимими (однаково специфрічні та чутливі) та підтвердили високу кореляцію зі стадіями відновлення свідомості після коми, для розрахунку ПІВС кожному з них було присвоєно числове значення 3,57 (100/27; де 28 - це n показників, а 100 - це числовий вираз цілого (коли всі показники у одного хворого діагностовано), для якого кожному показнику розраховано його частку \%). Таким чином, утворилося 28 показників зі значенням 3,57, що прогнозують позитивну динаміку відновлення свідомості і 28 показників зі значенням 3,57, що прогнозують негативну динаміку відновлення свідомості.

Відповідно до даних з таблиці 1 з'ясували кількість хворих, в яких на початку спостереження та в його кінці було або не було виявлено даних показників (табл. 2). 
ISSN 1681-276Х. ВІСНИК НАУКОВИХ ДОСЛІДЖЕНЬ. 2018. № 3

Таблиця 1. Зведені високоінформативні показники, що використані для розрахунку прогностичного індексу відновлення свідомості після тривалої церебральної посттравматичної коми

\begin{tabular}{|c|c|c|c|}
\hline \multicolumn{2}{|c|}{ Діагностичний показник із високою інсрормативністю } & $\begin{array}{c}\text { Динаміка відновлення свідомості: рух } \\
\text { за стадіями 1-8 } \\
\text { (Т. А. Доброхотова) } \\
\end{array}$ & $\begin{array}{c}\text { Відсутність динаміки відновлення } \\
\text { свідомості. Персистуючий } \\
\text { вегетативний статус } \\
\end{array}$ \\
\hline & 1 & 2 & 3 \\
\hline \multicolumn{2}{|c|}{ Рівень травматичної церебральної коми, ступінь } & $<\mathrm{III}$ & $\geq \mathrm{III}$ \\
\hline \multicolumn{2}{|c|}{ Причина ДТП } & Всі інші, крім ДТП & дтп \\
\hline \multicolumn{2}{|c|}{ Клінічний варіант черепно-мозкової травми } & Всі інші, крім ДАП & ДАП \\
\hline \multicolumn{2}{|c|}{ Посттравматичні вогнищеві зміни в речовині мозку за СКТ } & Середньої тяжкості & Тяжкі \\
\hline \multicolumn{2}{|c|}{ Посттравматичні дифузні зміни в речовині мозку за СКТ } & Середньої тяжкості & Тяжкі \\
\hline \multirow{3}{*}{ ССВП } & Амплітуда компонента N 20 & $\begin{array}{l}\text { Відповідає референтним значенням чи } \\
\text { дещо знижена }\end{array}$ & $\begin{array}{l}\text { Мала чи тільки на межі реєстрації } \\
\text { або компонент відсутній }\end{array}$ \\
\hline & ЧЦСП & $\begin{array}{l}\text { Відповідає ресерентним значенням чи } \\
\text { дещо збільшений }\end{array}$ & $\begin{array}{l}\text { Значення збільшення порівняно } 3 \\
\text { реферерентним значенням }\end{array}$ \\
\hline & $\begin{array}{l}\text { Динаміка показників N } 20 \text { (амплітуда, } \\
\text { латентність) та ЧЦСПу термін 1-6 місяців } \\
\text { після ЧМТ }\end{array}$ & $\begin{array}{l}\text { Покращувалися аж до ресрерентних } \\
\text { значень }\end{array}$ & $\begin{array}{l}\text { Відсутня, параметри відповідали } \\
\text { початковим }\end{array}$ \\
\hline \multicolumn{2}{|c|}{ Моторні пороги } & $<15-20 \%$ & $>15-20 \%$ \\
\hline \multirow{3}{*}{$\begin{array}{l}\text { Моторні ви- } \\
\text { кликані по- } \\
\text { тенціали }\end{array}$} & Амплітуда кіркових МВП & $\begin{array}{l}\text { Відповідає референтним значенням чи } \\
\text { дещо знижена }\end{array}$ & $\begin{array}{l}\text { Мала чи тільки на межі реєстрації } \\
\text { або компонент відсутній }\end{array}$ \\
\hline & Латентність кіркових МВП & $\begin{array}{l}\text { Відповідає референтним значенням чи } \\
\text { дещо підвищена }\end{array}$ & $\begin{array}{l}\text { Значення збільшення порівняно } 3 \\
\text { рефрерентним значенням }\end{array}$ \\
\hline & $\begin{array}{l}\text { Динаміка показників кіркових МВП (амп- } \\
\text { літуда, латентність) та ЧЦМП у термін } \\
\text { 1-6 місяців після ЧМП }\end{array}$ & $\begin{array}{l}\text { Покращувалася аж до ресрерентних } \\
\text { значень }\end{array}$ & $\begin{array}{l}\text { Відсутня, параметри відповідали } \\
\text { початковим }\end{array}$ \\
\hline \multirow{8}{*}{$\begin{array}{l}\text { КЕЕГ кіль- } \\
\text { кісні лінійні } \\
\text { показники }\end{array}$} & \multirow[t]{5}{*}{ Спектральний аналіз } & $\begin{array}{l}\text { Розширення спектра за рахунок спочат- } \\
\text { ку тета-, потім альфа- й бета-діапазонів } \\
\text { із міграцією основного піку частот від } \\
\text { дельта- до альфра-діапазону ( } ₫ к B / \sqrt{ } \text { Гц }\end{array}$ & Відсутність цієї ознаки \\
\hline & & $\begin{array}{l}\text { Індивідуальна стабільність потужнісних } \\
\text { характеристик (середньої потужності) } \\
\text { спектрів у межах конкретної стадії } 3 \\
\text { варіативністю реагування на подразни- } \\
\text { ки }\end{array}$ & $\begin{array}{l}\text { Варіабельність потужнісних характе- } \\
\text { ристик спектрів з ареактивністю чи } \\
\text { однотипністю реакцій на подразники } \\
\text { в одного і того ж пацієнта у межах } \\
\text { клінічної стадії на тлі потужностей } \\
\text { асиметрії із виразною частотною, } \\
\text { міжпівкульною асиметрією активнос- } \\
\text { ті в дельта-діапазоні }\end{array}$ \\
\hline & & $\begin{array}{l}\text { Зростання індексу активності “доміную- } \\
\text { чої гармоніки” зі зменшенням її асинх- } \\
\text { ронності }\end{array}$ & Відсутність цієї ознаки \\
\hline & & $\begin{array}{l}\text { 3ростання індексу бета-ритму, але } 3 \\
\text { наявністю в спектрі не більше двох піків } \\
\text { із частотою <20 гЦ }\end{array}$ & Відсутність цієї ознаки \\
\hline & & $\begin{array}{l}\text { 3ниження індексу дельта-ритму та його } \\
\text { міжпівкульної асиметрії ( } \leq 20 \% \text { у у пере- } \\
\text { дніх, передньо-центральних відділах } \\
\text { головного мозку }\end{array}$ & Відсутність цієї ознаки \\
\hline & \multirow[t]{3}{*}{ Кореляційний аналіз } & $\begin{array}{l}\text { Наростання ритмічності процесів у тета- } \\
\text { i альфра-діапазонах над ділянками, що } \\
\text { відповідають за інтегративні фрункції }\end{array}$ & Відсутність цієї ознаки \\
\hline & & $\begin{array}{l}\text { Зростання сили зв'язків без часткового } \\
\text { усуву між симетричними ділянками різ- } \\
\text { них півкуль }\end{array}$ & Відсутність цієї ознаки \\
\hline & & $\begin{array}{l}\text { Нормалізація часового зсуву між пере- } \\
\text { дніми і задніми відділами півкуль мозку }\end{array}$ & Відсутність цієї ознаки \\
\hline \multirow{4}{*}{$\begin{array}{l}\text { НЕЕГ кіль- } \\
\text { кісні нелі- } \\
\text { нійні показ- } \\
\text { ники }\end{array}$} & Величина ентропії & Великі значення ентропії $\geq 6-7$ & Малі значення ентропії <6 \\
\hline & Розмірність атрактора & $\begin{array}{l}\text { Велика розмірність атрокторів за усіма } \\
\text { відведеннями }\end{array}$ & $\begin{array}{l}\text { Мала розмірність атракторів за усіма } \\
\text { відведеннями }\end{array}$ \\
\hline & Властивості атракторів & Відсутність цієї ознаки & $\begin{array}{l}\text { Наявність "порожніх" зон у ділянці } \\
\text { відтворення атрактора }\end{array}$ \\
\hline & \begin{tabular}{|l} 
Грасрічна модель-координатор чисел \\
ентропії та розмірності в динаміці ЕЕГ- \\
досліджень для конкретного хворого
\end{tabular} & “Рух” точки в напрямку від осі координат & $\begin{array}{l}\text { Відсутність змін, ділянка положення } \\
\text { точок та ж сама }\end{array}$ \\
\hline
\end{tabular}




\begin{tabular}{|c|c|c|}
\hline \multirow[b]{2}{*}{1} & \multicolumn{2}{|r|}{ Продовження табл. 1} \\
\hline & 2 & 3 \\
\hline Складність нейродинамічної системи & $\begin{array}{l}\text { Наростання складності динамічних сис- } \\
\text { тем у часі }\end{array}$ & $\begin{array}{l}\text { Стала складність динамічних систем } \\
\text { у часі }\end{array}$ \\
\hline Характеристики основного сигналу & $\begin{array}{l}\text { Шум є, але невиразний і не впливає на } \\
\text { показники ентропії та розмірності }\end{array}$ & $\begin{array}{l}\text { Домінування в структурі основного } \\
\text { сигналу хворих із ВС шумової скла- } \\
\text { дової }\end{array}$ \\
\hline Розмірність домінуючого монофракталу & $\begin{array}{l}\text { Велика розмірність домінуючого моно- } \\
\text { фракталу }(0,70 \pm 0,04), \text { що в часі тільки } \\
\text { зростає }(0,75 \pm 0,03)\end{array}$ & $\begin{array}{l}\text { Знижена розмірність домінуючого } \\
\text { монофрактату із великим розкидом } \\
\text { значень }(0,64 \pm 0,07)\end{array}$ \\
\hline Ширина мультисррактального спектра & $\begin{array}{l}\text { Зменшена ширина мультифрактального } \\
\text { спектра }(0,71 \pm 0,03) \text {, чисельність, гене- } \\
\text { руючи “шум” динамічних систем, змен- } \\
\text { шилася, або знизилася їх активність) та } \\
\text { продовжує в часі зменшуватися } \\
(0,60 \pm 0,03)\end{array}$ & $\begin{array}{l}\text { 3начна ширина мультифрактально- } \\
\text { го спектра }(0,76 \pm 0,03) \text { вказує на ге- } \\
\text { нерацію “шуму” багатьма динамічни- } \\
\text { ми системами, малопов'язаними між } \\
\text { собою }\end{array}$ \\
\hline
\end{tabular}

Таблиця 2. Зведені високоінформативні показники залежно від кількості хворих, у яких їх виявили, або не виявили протягом періоду спостереження

\begin{tabular}{|c|c|c|c|c|c|c|}
\hline \multirow{3}{*}{$\begin{array}{c}\text { Порядковий } \\
\text { номер } \\
\text { показника }\end{array}$} & \multirow{2}{*}{$\begin{array}{c}\text { Значення } \\
\text { показника для } \\
\text { динаміки віднов- } \\
\text { лення свідомості } \\
\text { (стадії 1-8) }\end{array}$} & \multicolumn{2}{|c|}{$\begin{array}{c}\text { Кількість хворих, у яких він був } \\
\text { виявлений, n }\end{array}$} & \multirow{2}{*}{$\begin{array}{c}\text { Значення } \\
\text { показника для } \\
\text { ВС (відсутність } \\
\text { динаміки віднов- } \\
\text { лення свідомості) }\end{array}$} & \multicolumn{2}{|c|}{$\begin{array}{c}\text { Кількість хворих, у яких він був } \\
\text { виявлений, n }\end{array}$} \\
\hline & & $\begin{array}{c}\text { на початку } \\
\text { спостереження }\end{array}$ & $\begin{array}{c}\text { у кінці } \\
\text { спостереження }\end{array}$ & & $\begin{array}{c}\text { на початку } \\
\text { спостереження }\end{array}$ & $\begin{array}{c}\text { у кінці } \\
\text { спостереження }\end{array}$ \\
\hline & $\mathrm{m}$ & $\mathrm{n} 1$ & $\mathrm{n} 2$ & 3,57 & 11,00 & 11,00 \\
\hline 1 & 3,57 & 209 & 209 & 3,57 & 24 & 24 \\
\hline 2 & 3,57 & 77 & 77 & 3,57 & 24 & 24 \\
\hline 3 & 3,57 & 186 & 186 & 3,57 & 24 & 24 \\
\hline 4 & 3,57 & 177 & 129 & 3,57 & 24 & 24 \\
\hline 5 & 3,57 & 186 & 121 & 3,57 & 24 & 24 \\
\hline 6 & 3,57 & 1 & 186 & 3,57 & 24 & 24 \\
\hline 7 & 3,57 & 2 & 192 & 3,57 & 24 & 24 \\
\hline 8 & 3,57 & 1 & 196 & 3,57 & 23 & 22 \\
\hline 9 & 3,57 & 1 & 196 & 3,57 & 23 & 24 \\
\hline 10 & 3,57 & 2 & 167 & 3,57 & 24 & 24 \\
\hline 11 & 3,57 & 1 & 161 & 3,57 & 24 & 24 \\
\hline 12 & 3,57 & 2 & 196 & 3,57 & 24 & 24 \\
\hline 13 & 3,57 & 1 & 181 & 3,57 & 24 & 24 \\
\hline 14 & 3,57 & 3 & 179 & 3,57 & 24 & 24 \\
\hline 15 & 3,57 & 1 & 187 & 3,57 & 24 & 24 \\
\hline 16 & 3,57 & 3 & 196 & 3,57 & 24 & 24 \\
\hline 17 & 3,57 & 5 & 196 & 3,57 & 24 & 24 \\
\hline 18 & 3,57 & 2 & 138 & 3,57 & 24 & 24 \\
\hline 19 & 3,57 & 1 & 132 & 3,57 & 24 & 24 \\
\hline 20 & 3,57 & 1 & 112 & 3,57 & 24 & 24 \\
\hline 21 & 3,57 & 1 & 93 & 3,57 & 24 & 24 \\
\hline 22 & 3,57 & 1 & 90 & 3,57 & 24 & 24 \\
\hline 23 & 3,57 & 3 & 92 & 3,57 & 24 & 24 \\
\hline 24 & 3,57 & 2 & 194 & 3,57 & 24 & 23 \\
\hline 25 & 3,57 & 1 & 138 & 3,57 & 22 & 24 \\
\hline 26 & 3,57 & 54 & 46 & 3,57 & 24 & 24 \\
\hline 27 & 3,57 & 2 & 46 & 3,57 & 24 & 24 \\
\hline 28 & 3,57 & 1 & 46 & 3,57 & 24 & 24 \\
\hline
\end{tabular}

Всі необхідні дані обчислюємо за фрормулою [1]:

$\Pi$ ІВС $=\Sigma\left(\left(n_{2} \times m\right)-\left(n_{4} \times m\right)\right) /\left(\left(n_{1} \times m_{1}\right)-\left(n_{3} \times m_{1}\right)\right) / N \times 100 \%$ де, $N$ - кількість символів індексованих показників розраховано прогностичний індекс відновлення свідомості, який склав ПІВС $=-90,5$ \% (з негативним знаком). Ця величина є досить великою і вказує на те, що, якщо у пацієнта не будуть виявлені одночасно не менше (вони рівноцінні) 25 будь-яких сприятливих прогностичних показників
$(90,5$ \%/3,57 \%)) із 28 відібраних (колонка 2+3, табл. 1), прогноз відновлення свідомості з великою вірогідністю швидше буде негативним. I навпаки, якщо у пацієнта одночасно буде встановлено 25 і більше прогностичних сприятливих показників, вірогідність у позитивній динаміці свідомості велика.

Проте необхідно зазначити, що оскільки мова йде про величину індексу, немало важливим залишається 
його зміна в часі. Тому, якщо на початку спостереження кількість прогностичних показників менша 25, але в ході дообстеження додаються нові, що врешті-решт призводить до набору потрібного значення, то обґрунтовано можна очікувати покращення рівня свідомості, адже вище зазначалося про їх виразну доклінічну інформативність.

Як зазначалося вище, з метою підвищення надійності отриманих результатів, аналогічні розрахунки були проведені й у контрольній групі хворих, де аналогічні стадії відновлення свідомості мали місце упродовж року, але після тяжкого гострого гіпоксичного, аноксичного уражень головного мозку.

Перш ніж аналізувати інформативні показники, провели вивчення динаміки посткоматозних станів у цих хворих з моменту, коли було діагностовано вегетативний статус і до моменту встановлення синдрому ясної свідомості упродовж періоду спостереження. Утворився наступний кількісний розподіл випадків (контрольна група), які в межах року після ГПМК перейшли до наступної стадії відновлення свідомості, чи лишилися на якійсь одній із них (табл. 3).
Як свідчать дані з таблиці, перебіг посткоматозного періоду після гострого порушення мозкового кровотоку характеризувався значно гіршими наслідками щодо відновлення преморбітної свідомості порівняно з основною групою дослідження. Кількість хворих, у яких відновився ясний рівень свідомості, становить лише $10 \%(n=3)$, разом 3 тим, як у травмованих хворих - 21,91 \% ( $n=46)$. Пацієнти, які так і не вийшли з вегетативного стану упродовж року з моменту ГПМК, складають 40 \% (n=12), що майже в 4 рази перевищує аналогічний результат у хворих після тяжкої ЧМТ $(10,91 \%$; $=24)$. Вірогідно, така ситуація неодмінно відобразиться на значеннях інформативних показників у хворих групи контролю.

Здійснивши подальші обчислення, виявилося, що у цих пацієнтів серед високоінформативних показників були всі ті ж самі нейрофізіологічні та нейровізуалізаційні, лише з певними акцентами та деякими відмінними значеннями, окрім анамнестичних, де в силу іншого нозологічного явища зміни очікувані (табл. 4).

Аналогічно в основній групі дослідження провели визначення кількості хворих, котрі протягом періоду спостереження володіли вказаними показниками (табл. 5).

Таблиця 3. Кількісний поділ хворих (контрольна група), які упродовж року після гострого порушення мозкового кровотоку, досягнувши певної стадії відновлення свідомості (N1), так і залишилися в ній (n)

\begin{tabular}{|c|c|c|c|c|}
\hline № $3 a / п$ & Стадія посткоматозного порушення/відновлення свідомості за Т. А. Доброхотовою*夫夫 & N1 & $\mathrm{n}$ & $\%(\mathrm{~N}=220)$ \\
\hline 1 & $1-\mathrm{BC}$ & 30 & 12 & 40,00 \\
\hline 2 & 2A-AKM & 18 & 5 & 27,78 \\
\hline 3 & 2Б-ГКМ & 13 & 3 & 23,08 \\
\hline 4 & 3A-AKM 3 EP & 10 & 1 & 10,00 \\
\hline 5 & ЗБ-ГКМ 3 ЕР & 9 & 1 & 11,11 \\
\hline 6 & 4-M 3 PM & 8 & 1 & 12,50 \\
\hline 7 & 5-ДМ & 7 & 1 & 14,29 \\
\hline 8 & 6А-СПС 3 A & 6 & 0 & 0,00 \\
\hline 9 & 6Б-МРCC & 6 & 0 & 0,00 \\
\hline 10 & 6B-ACC & 6 & 1 & 16,67 \\
\hline 11 & 7А-ДС & 5 & 1 & 20,00 \\
\hline 12 & 7Б-KC & 4 & 1 & 25,00 \\
\hline 13 & 8-ЯС 3 КЕР & 3 & 3 & $100\left(10^{\star}\right)$ \\
\hline 14 & 9-ЯС з ПП & 0 & 0 & 0,00 \\
\hline 15 & 10-ЯС з ПМС & 0 & 0 & 0,00 \\
\hline
\end{tabular}

Примітка: *** - 1-ВС - вегетативний стан; 2А-АКМ - акінетичний мутизм; 2Б-ГКМ - гіперкінетичний мутизм; ЗА-АКМ 3 ЕР - акінетичний мутизм 3 емоційними реакціями; ЗБ-ГКМ 3 ЕР - гіперкінетичний мутизм з емоційними реакціями; 4-М з РМ - мутизм з розумінням мови; 5-ДМ - дезінтеграція мови; 6А-СПС 3 А - сплутаність свідомості з аспонтанністю; 6Б-МРСС - мовнорухова сплутаність свідомості; 6В-АСС - амнестична сплутаність свідомості; 7А-ДС - дисмнестичний синдром; 7Б-КС - Корсаковський синдром; 8-ЯС з КЕР - ясна свідомість 3 виразними когнітивними, вольовими та емоційними порушеннями; 9-ЯС з ПП-ясна свідомість з пограничними порушеннями; 10-ЯС з ПМС - ясна свідомість з преморбітним рівнем психічного стану.

Таблиця 4. Зведені високоінформативні показники, які використано для розрахунку прогностичного індексу відновлення свідомості після тривалої церебральної коми унаслідок гострого порушення мозкового кровотоку

\begin{tabular}{|c|c|c|}
\hline Діагностичний показник із високою інфоомативністю & $\begin{array}{l}\text { Динаміка відновлення свідомості: рух } \\
\text { за стадіями 1-8 (Т. А. Доброхотова) }\end{array}$ & $\begin{array}{c}\text { Відсутність динаміки } \\
\text { відновлення свідомості. } \\
\text { Персистуючий вегетативний } \\
\text { статус }\end{array}$ \\
\hline 1 & 2 & \begin{tabular}{|c|}
3 \\
\end{tabular} \\
\hline Рівень травматичної церебральної коми, ступінь & I & $\geq 11$ \\
\hline Причина ГПМК & Гемодинамічна & $\begin{array}{l}\text { Кардіальна } \\
\text { (зупинка серця) }\end{array}$ \\
\hline Клінічний ГПМК & Ішемічний & Змішаний \\
\hline Посттравматичні вогнищеві зміни в речовині мозку за МРТ & 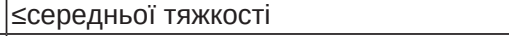 & Тяжкі \\
\hline Посттравматичні диффузні зміни в речовині мозку за МРТ & Легкі & >середньої тяжкості \\
\hline
\end{tabular}


Продовження табл. 4

\begin{tabular}{|c|c|c|c|}
\hline \multicolumn{2}{|r|}{1} & 2 & 3 \\
\hline \multirow[t]{3}{*}{ ССВП } & Амплітуда компонента N 20 & $\begin{array}{l}\text { Відповідає референтним значенням чи } \\
\text { дещо знижена }\end{array}$ & $\begin{array}{l}\text { Мала чи тільки на межі реє- } \\
\text { страції або компонент відсутній }\end{array}$ \\
\hline & ЧЦСП & $\begin{array}{l}\text { Відповідає ресерентним значенням чи } \\
\text { дещо збільшений }\end{array}$ & $\begin{array}{l}\text { Значне збільшення, порівняно } \\
3 \text { рефрерентним значенням, } \\
\text { або не можливо визначити }\end{array}$ \\
\hline & $\begin{array}{l}\text { Динаміка показників N } 20 \text { (амплітуда, латент- } \\
\text { ність) та ЧЦСП у термін 1-6 місяців після ЧМТ }\end{array}$ & $\begin{array}{l}\text { Покращувалися аж до рефрерентних } \\
\text { значень }\end{array}$ & $\begin{array}{l}\text { Відсутня, параметри відпо- } \\
\text { відали початковим }\end{array}$ \\
\hline \multicolumn{2}{|c|}{ Моторні пороги } & $<15-20 \%$ & $>15-20 \%$ \\
\hline \multirow[t]{3}{*}{$\begin{array}{l}\text { Моторні ви- } \\
\text { кликані по- } \\
\text { тенціали }\end{array}$} & Амплітуда кіркових МВП & $\begin{array}{l}\text { Відповідає референтним значенням чи } \\
\text { дещо знижена }\end{array}$ & $\begin{array}{l}\text { Мала чи тільки на межі реє- } \\
\text { страції або компонент від- } \\
\text { сутній }\end{array}$ \\
\hline & Латентність кіркових МВП & $\begin{array}{l}\text { Відповідає референтним значенням чи } \\
\text { дещо підвищена }\end{array}$ & $\begin{array}{l}\text { Значне збільшення, порівняно } \\
3 \text { референтним значенням, } \\
\text { або не можливо визначити } \\
\end{array}$ \\
\hline & $\begin{array}{l}\text { Динаміка показників кіркових МВП (амплітуда, } \\
\text { латентність) та ЧЦМП у термін 1-6 місяців } \\
\text { після ЧМТ }\end{array}$ & $\begin{array}{l}\text { Покращувалися аж до референтних } \\
\text { значень }\end{array}$ & $\begin{array}{l}\text { Відсутня, параметри відпо- } \\
\text { відали початковим }\end{array}$ \\
\hline \multirow[t]{8}{*}{$\begin{array}{l}\text { КЕЕГ кількісні } \\
\text { лінійні показ- } \\
\text { ники }\end{array}$} & \multirow[t]{5}{*}{ Спектральний аналіз } & $\begin{array}{l}\text { Розширення спектра за рахунок спо- } \\
\text { чатку тета-, потім альфа- й бета-діа- } \\
\text { пазонів із міграцією основного піку } \\
\text { частот від дельта- до альфа-діапазону } \\
(\uparrow \text { мкВ/لГц) }\end{array}$ & Відсутність цієї ознаки \\
\hline & & \begin{tabular}{|l} 
Індивідуальна стабільність потужнісних \\
характеристик (середньої потужності) \\
спектрів у межах конкретної стадії із \\
варіативністю реагування на подразни- \\
ки \\
\\
\\
\end{tabular} & $\begin{array}{l}\text { Варіабельність потужнісних } \\
\text { характеристик спектрів } 3 \\
\text { ареактивністю чи однотип- } \\
\text { ністю реакцій на подразники } \\
\text { в одного і того ж пацієнта в } \\
\text { межах клінічної стадії на тлі } \\
\text { потужнісної асиметрії із ви- } \\
\text { разною частотною, міжпів- } \\
\text { кульною асиметрією актив- } \\
\text { ності в дельта-діапазоні } \\
\end{array}$ \\
\hline & & $\begin{array}{l}\text { Зростання індексу активності “доміну- } \\
\text { ючої гармоніки” із зменшенням її асинх- } \\
\text { ронності }\end{array}$ & Відсутність цієї ознаки \\
\hline & & $\begin{array}{l}\text { 3ростання індексу бета-ритму, але } 3 \\
\text { наявністю в спектрі не більше двох піків } \\
\text { із частотою <20 Гц }\end{array}$ & Відсутність цієї ознаки \\
\hline & & $\begin{array}{l}\text { Зниження індексу дельта-ритму та його } \\
\text { міжпівкульної асиметрії (<20 \%) у пере- } \\
\text { дніх, передньо-центральних відділах } \\
\text { головного мозку }\end{array}$ & Відсутність цієї ознаки \\
\hline & \multirow[t]{3}{*}{ Кореляційний аналіз } & $\begin{array}{l}\text { Наростання ритмічності процесів у } \\
\text { тета- і альфра-діапазонах над ділянка- } \\
\text { ми, що відповідають за інтегративні } \\
\text { функції }\end{array}$ & Відсутність цієї ознаки \\
\hline & & $\begin{array}{l}\text { Зростання сили зв'язків без часового } \\
\text { зсуву між симетричними ділянками } \\
\text { різних півкуль }\end{array}$ & Відсутність цієї ознаки \\
\hline & & $\begin{array}{l}\text { Нормалізація часового зсуву між пере- } \\
\text { дніми і задніми відділами півкуль мозку }\end{array}$ & Відсутність цієї ознаки \\
\hline \multirow{6}{*}{$\begin{array}{l}\text { КЕЕГ кількісні } \\
\text { нелінійні по- } \\
\text { казники }\end{array}$} & Величина ентропії & Великі значення ентропії >6-7 & Малі значення ентропії <6 \\
\hline & Розмірність атрактора & $\begin{array}{l}\text { Велика розмірність атрокторів за усіма } \\
\text { відведеннями }\end{array}$ & $\begin{array}{l}\text { Мала розмірність атракторів } \\
\text { за усіма відведеннями }\end{array}$ \\
\hline & Властивостивості атракторів & Відсутність цієї ознаки & $\begin{array}{l}\text { Наявність "порожніх" зон у } \\
\text { ділянці відтворення атрактора }\end{array}$ \\
\hline & $\begin{array}{l}\text { Графрічна модель координат чисел ентропії та } \\
\text { розмірності в динаміці ЕЕГ-досліджень для } \\
\text { конкретного хворого }\end{array}$ & “Рух” точки в напрямку від осі координат & $\begin{array}{l}\text { Відсутність змін, ділянка по- } \\
\text { ложення точок та ж сама }\end{array}$ \\
\hline & Складність нейродинамічної системи & $\begin{array}{l}\text { Наростання складності динамічних } \\
\text { систем в часі }\end{array}$ & $\begin{array}{l}\text { Стала складність динамічних } \\
\text { систем у часі }\end{array}$ \\
\hline & Характеристики основного сигналу & $\begin{array}{l}\text { Шум є, але невиразний і не впливає на } \\
\text { показники ентропії та розмірності }\end{array}$ & $\begin{array}{l}\text { Домінування у структурі осно- } \\
\text { вного сигналу хворих із ВС } \\
\text { шумової складової }\end{array}$ \\
\hline
\end{tabular}




\begin{tabular}{|c|c|c|}
\hline 1 & 2 & 3 \\
\hline Розмірність домінуючого монофракталу & $\begin{array}{l}\text { Велика розмірність домінуючого } \\
\text { монофракталу }(0,78 \pm 0,03) \text {, що з часом } \\
\text { тільки зростає }(0,81 \pm 0,04)\end{array}$ & $\begin{array}{l}\text { Знижена розмірність } \\
\text { домінуючого монофрракталу } \\
\text { із великим розкидом } \\
\text { значень }(0,63 \pm 0,02) \\
\end{array}$ \\
\hline Ширина мультифррактального спектра & $\begin{array}{l}\text { Зменшена ширина мультифракталь- } \\
\text { ного спектра }(0,76 \pm 0,02) \text { (чисельність } \\
\text { динамічних систем, що генерують } \\
\text { "шум" зменшилася, або знизилася їх } \\
\text { активність) та продовжує з часом } \\
\text { зменшуватися }(0,67 \pm 0,02)\end{array}$ & $\begin{array}{l}\text { Значна ширина мультифрак- } \\
\text { тального спектра }(0,79 \pm 0,04) \\
\text { вказує на генерацію “шуму" } \\
\text { багатьма динамічними систе- } \\
\text { мами, малопов'язаними між } \\
\text { собою }\end{array}$ \\
\hline
\end{tabular}

Таблиця 5. Зведені високоінформативні показники, залежно від кількості хворих із наслідками тяжкого гострого порушення мозкового кровотоку, в яких вони були виявлені, або не виявлені протягом періоду спостереження

\begin{tabular}{|c|c|c|c|c|c|c|}
\hline \multirow{3}{*}{ № $3 а / п$} & \multirow{2}{*}{$\begin{array}{c}\text { Значення } \\
\text { показника для } \\
\text { динаміки віднов- } \\
\text { лення свідомості } \\
\text { (стадії 1-8) }\end{array}$} & \multicolumn{2}{|c|}{$\begin{array}{c}\text { Кількість хворих із ГПМК, у яких він } \\
\text { був виявлений, n } \\
\end{array}$} & \multirow{2}{*}{$\begin{array}{c}\text { Значення показника } \\
\text { для ВС (відсутність } \\
\text { динаміки відновлен- } \\
\text { ня свідомості) }\end{array}$} & \multicolumn{2}{|c|}{$\begin{array}{c}\text { Кількість хворих із ГПМК, у яких } \\
\text { він був виявлений, n }\end{array}$} \\
\hline & & $\begin{array}{c}\text { на початку } \\
\text { спостереження }\end{array}$ & $\begin{array}{c}\text { у кінці спостере- } \\
\text { ження }\end{array}$ & & $\begin{array}{c}\text { на початку } \\
\text { спостереження }\end{array}$ & $\begin{array}{c}\text { у кінці } \\
\text { спостереження }\end{array}$ \\
\hline & $\mathrm{m}$ & $\mathrm{n} 1$ & $\mathrm{n} 2$ & $\mathrm{~m} 1$ & n3 & $\mathrm{n} 4$ \\
\hline 1 & 3,57 & 18 & 18 & 3,57 & 12 & 12 \\
\hline 2 & 3,57 & 12 & 12 & 3,57 & 8 & 8 \\
\hline 3 & 3,57 & 17 & 17 & 3,57 & 11 & 11 \\
\hline 4 & 3,57 & 18 & 18 & 3,57 & 12 & 12 \\
\hline 5 & 3,57 & 18 & 18 & 3,57 & 12 & 12 \\
\hline 6 & 3,57 & 3 & 6 & 3,57 & 12 & 12 \\
\hline 7 & 3,57 & 2 & 5 & 3,57 & 12 & 12 \\
\hline 8 & 3,57 & 1 & 8 & 3,57 & 11 & 12 \\
\hline 9 & 3,57 & 1 & 7 & 3,57 & 11 & 12 \\
\hline 10 & 3,57 & 2 & 8 & 3,57 & 11 & 12 \\
\hline 11 & 3,57 & 5 & 8 & 3,57 & 12 & 12 \\
\hline 12 & 3,57 & 2 & 8 & 3,57 & 11 & 12 \\
\hline 13 & 3,57 & 1 & 8 & 3,57 & 11 & 10 \\
\hline 14 & 3,57 & 1 & 7 & 3,57 & 11 & 12 \\
\hline 15 & 3,57 & 1 & 8 & 3,57 & 12 & 12 \\
\hline 16 & 3,57 & 1 & 8 & 3,57 & 12 & 12 \\
\hline 17 & 3,57 & 1 & 6 & 3,57 & 12 & 10 \\
\hline 18 & 3,57 & 2 & 8 & 3,57 & 12 & 11 \\
\hline 19 & 3,57 & 1 & 8 & 3,57 & 12 & 10 \\
\hline 20 & 3,57 & 1 & 8 & 3,57 & 12 & 11 \\
\hline 21 & 3,57 & 1 & 4 & 3,57 & 12 & 12 \\
\hline 22 & 3,57 & 1 & 5 & 3,57 & 12 & 12 \\
\hline 23 & 3,57 & 1 & 7 & 3,57 & 12 & 12 \\
\hline 24 & 3,57 & 1 & 3 & 3,57 & 12 & 12 \\
\hline 25 & 3,57 & 1 & 3 & 3,57 & 11 & 12 \\
\hline 26 & 3,57 & 1 & 4 & 3,57 & 12 & 12 \\
\hline 27 & 3,57 & 2 & 3 & 3,57 & 12 & 12 \\
\hline 28 & 3,57 & 1 & 3 & 3,57 & 12 & 12 \\
\hline
\end{tabular}

Розрахувавши прогностичний індекс відновлення свідомості для цієї групи хворих, отримали ПІВC=+62 \% (вже з позитивним знаком). Ця величина хоч і менша, але через позитивний знак свідчить про те, що, коли в одного пацієнта одночасно буде виявлено більше 17 несприятливих прогностичних показників (колонка 2+4, табл.1), виникає велика ймовірність залишитися у вегетативному статусі. Однак аналогічно з пацієнтом основної групи дослідження, якщо в динаміці ця кількість несприятливих прогностичних показників буде знижуватися, то вірогід- ність покращення рівня свідомості надоклінічному етапі зростає.

Перевіривши взаємозв'язок отриманих ПІВС для двох груп спостереження, встановили, що вони пов'язані між собою так само, як їхні індексовані показники (табл. 2, 5).

ВИСНОВКИ 1. Розраховані прогностичні індекси відновлення свідомості, в основу яких було покладено 28 високоінформативних показників, 23 з яких є нейрофрізіологічними, 2 нейровізуалізаційними, володіють високою практичною значимістю як для прогнозування динаміки відновлення 
свідомості, так іпланування тактики подальших реабілітаційних заходів з оцінкою їх вірогідної есрективності.

2. Нейрофрізіологічні методи діагностики (кількісна EEГ) мають суттєву перевагу над нейровізуалізуючими (СКТ, МРТ) в прогнозуванні відновлення свідомості після тривалої постравматичної коми.

3. Найінфрормативнішою та найчутливішою виявилася група показників нелінійної нейродинаміки та детермінованого хаосу: ентропія, розмірності атракторів, мультифррактальні властивості сигналів ЕЕГ, а також показників кореляційного та спектрального аналізів.

\section{СПИСОК ЛІТЕРАТУРИ}

1. Васнев С. А. Статистика : учеб. пособ. / С. А. Васнев. - М. : МГУП, 2001. - 170 с

2. Городник Г. А. Прогнозирование исхода крайне тяжелой черепно-мозговой травмы. Диагностика смерти мезга / Г. А. Городник // Травма. -2010. - Т. 11, № 1. - С. 20-30.

3. Городник Г. А. Диагностика смерти мозга у нейрохирургических больных / Г. А. Городник, В. И. Черний, Е. В. Лазарева // IV з'їзд нейрохірургів України, 27-30 трав. 2008 р. - Дніпропетровськ, 2008. - С. 186.

4. Гук А. П. Епідеміологія черепно-мозкової травми в Україні / А. П. Гук // Матеріали V з'їзду нейрохірургів України, 25-28 червня, 2013. - Ужгород, 2013. - С. 38.

5. Дзяк Л. А. Поэтапная модель прогноза исходов тяжелой черепно-мозговой травмы / Л. А. Дзяк, О. А. Зозуля // Медицина невідкладних станів. - 2016. - № 4 (75). - С 79-82.

6. Ельский В. Н. Патофизиология, диагностика и интенсивная терапия тяжелой черепно-мозговой травмы : рук-во для врачей / В. Н. Ельский, А. М. Кардаш, Г. А. Городник; под ред. В. И. Черния. - Донецк, 2004. - 200 с

7. Зайцев О. С. Нейрореаниматология. Выход из комы (терапия посткоматозных состояний) / О. С. Зайцев, С. В. Царенко. - М. : Литасс, 2012. - С. 7-27.

8. Зайцев О. С. Нейрореаниматология. Выход из комы (терапия посткоматозных состояний) / О. С. Зайцев, С.В.Царенко. - М. : Литасс, 2012. - С. 24-25.

9. Казинец Л. С. О некоторых формальных приемах индексного анализа / Л. С. Казинец // Статистика. - 2001. - № 12. - С. 27-30.

10. Кулик О. В. Оцінка інсормативності нейрофрізіологічних методів діагностики стану сенсомоторної системи хворих у підгострому періоді тяжкої черепно-мозкової травми / О.В.Кулик, А. І. Третьякова // Український нейрохірургічний журнал. - 2016. - № 1 - С. 67-72.

11. Мещеряков С. Прогнозирование исходов тяжелой череп-
4. Саме ці показники і їх значення утворювали 16328 специфічних індексованих величин, одночасна наявність чи відсутність яких у конкретного хворого на конкретній стадії відновлення свідомості фрормувала ядро їх прогностичного індексу відновлення, а динаміка змін у часі доклінічно свідчила про напрямок еволюції біоелектричної активності головного мозку, а від так і еквівалентних коркових фрункцій.

5. Всі решта методів проведеної діагностики були допоміжними і тільки посилювали, або послаблювали ймовірний прогноз.

но-мозговой травмы у детей : дис. ... канд. мед. наук : 14.01.18 / Семен Владимирович Мещеряков. - М., 2017. - 145 с.

12. Педаченко Є. Г. Сучасні підходи та інноваційні технології в лікуванні черепно-мозкової травми // Матеріали $\vee$ з"їзду нейрохірургів України, 25-28 червня 2013. - Ужгород, 2013. - С. 52-53.

13. Черепно-мозкова травма: сучасні принципи невідкладної допомоги : навч. метод. посіб. / Є. Г. Педаченко, І. П. Шлапак, А. П. Гук, М. М. Пилипенко. - Київ : Варта, 2007. - 311 с.

14. Полищук Н. Е. Унисикация объема диагностики и медицинской помощи больным с черепно-мозговой травмой / Н. Е. Полищук, С. Ю. Рассказов // Український нейрохірургічний журнал. - 2000. - № 1 (9). - С. 73-77.

15. Пат. Способ прогнозирования постреанимационного периода / Новикова Р. И., Черний В. И., Городник Г. А., Момот Н. В., Соловьева Е. М. - № 1809757 ; заявл. 10.10.1992.

16. Статистика : підручн. / [С. С. Герасименко, А. В. Головач, А. М. Єріна та ін.] ; за наук. ред. С. С. Герасименка. - 2-ге вид., перероб. і доп. - К. : КНЕУ, 2000. - 467 с.

17. Тяжелая черепно-мозговая травма: структура осложнений и летальности / [В. К. Орлов, Ф. А. Фархат, А. И. Аверочкин и др.] // Материалы III съезда нейрохирургов России, 4-8 июня, 2002. - СПб., 2002. - С. 54-55.

18. Черний В. И. Оценка эффективности терапии при тяжелой черепно-мозговой травме: метод логарифмических индексов параметров количественной ЭЭГ / В. И. Черний, И. А. Андронова, Т. В. Черний // Міжнародний неврологічний журнал. - 2008. - № 4 (26). - С. 61-70.

19. Принципы и методы диагностики и интенсивной терапии тяжелой черепно-мозговой травмы : метод. рекоменд. / [В. И. Черний, А. М. Кардаш, Г. А. Городник и др.]. - Донецк, 2003. - 58 с.

20. Черній В. І., Головний мозок при термінальному стані / В. І. Черній, А. І. Шевченко, Г. А. Городник. - Донецьк : Наука і освіта, 2000. - 220 c.

21. Plum F. The Diagnosis of Stupor and Coma / F. Plum, J. B. Posner. - Philadelphia : Davis F.A. Company, 1985. - P. 96-100.

Отримано 03.08.18

Електронна адреса для листування: eago@ukr.net

○OO. V. Kulyk

Scientific and Practical Center of Neuro-Rehabilitation "Nodus"

\section{PROGNOSTIC INDEX OF CONSCIOUSNESS RECOVERY IN PATIENTS WITH ITS LONG-TERM DISORDERS AFTER SEVERE} TRAUMATIC BRAIN INJURY

Summary. The work is based on the results of diagnosis, rehabilitation and restorative treatment of 220 patients with post-coma long-term consciousness disorders after a severe head injury. The main attention is paid to the actual topic of predicting the restoration of consciousness in accordance with the stages of classification of Dobrokhotova T. A. in the course of the rehabilitation route. The features of 28 key consolidated highly informative indicators used to calculate the prognostic index of consciousness recovery are 
analyzed, the analysis of poorly researched and currently disputed questions regarding their correlation with clinical indices of the transition from vegetative status to the higher stages of post-coma consciousness syndromes is carried out. The study emphasizes that the prognostic index of consciousness restoration performed a practical and determining function, and was not only a condition for planning the tactics of further rehabilitation measures and determining their likely effectiveness. Based on the obtained data, a conclusion on the significant advantage of neurophysiological diagnostic methods (quantitative EEG) over neuroimaging (CKT, MRI) in predicting the recovery of consciousness after a long-lasting post-traumatic coma is made. The group of indices of nonlinear neurodynamics and deterministic chaos: entropy, dimensions of attractors, multifractal properties of EEG signals, as well as indicators of correlation and spectral analysis were the most informative and sensitive. These are the indicators and their values that formed 16 out of 28 specific indexed quantities, the simultaneous presence or absence of which in a particular patient of a particular stage of consciousness recovery formed the core of their prognostic recovery index, and the dynamics of changes in the course of time preclinically reflected the evolution of the bioelectrical activity of the brain, and hence also equivalent cortical functions. All other methods of diagnosis were assisted and only strengthened or weakened the probable prognosis.

Key words: quantitative electroencephalography; traumatic brain injury; post-coma disturbance of consciousness; non-linear EEG analysis; attractor; dynamic system; entropy; deterministic chaos; information dimension; prognostic recovery index.

\section{ПРОГНОСТИЧЕСКИЙ ИНДЕКС ВОЗОБНОВЛЕНИЯ СОЗНАНИЯ У ПАЦИЕНТОВ С ДЛИТЕЛЬНЫМИ ЕЕ РАССТРОЙСТВАМИ ПОСЛЕ ТЯЖЕЛОЙ ЧЕРЕПНО-МОЗГОВОЙ ТРАВМЫ}

Резюме. В основу работы положены результаты диагностики, реабилитации и восстановительного лечения 220-ти больных с посткоматозными длительными расстройствами сознания после тяжелой черепно-мозговой травмы (ЧМТ). Главное внимание уделяют актуальной теме прогнозирования возобновления сознания в соответствии со стадиями классификации Т. А. Доброхотовой в ходе реабилитационного маршрута. Раскрыты особенности 28-ми ключевых возведенных высокоинформативных показателей, которые использовали для расчета прогностического индекса возобновление сознания, проведен анализ малоизученных и спорных доныне вопросов относительно их корреляции с клиническими показателями перехода от вегетативного статуса к высшим стадиям синдромов посткоматозного сознания. В исследовании акцентируется на том, что прогностический индекс возобновления сознания выполнял практическую и определяющую функцию, а не был лишь условием в планировании тактики дальнейших реабилитационных мероприятий и определении их достоверной эффеетивности. На основе полученных данных сделали вывод о существенном преимуществе нейрофризиологических методов диагностики (количественной ЭЭГ) над нейровизуализирующими (СКТ, МРТ) в прогнозировании возобновления сознания после длительной постравматичной комы. Информативной и самой чувствительной оказалась группа показателей нелинейной нейродинамики и детерминированного хаоса : энтропия, размерности атракторов, мультисррактальные свойства сигналов ЭЭГ, а также показателей корреляционного и спектрального анализа. Именно эти показатели и их значения образовывали 16 с 28-ми специфических индексированных величин, одновременное наличие или отсутствие которых у конкретного больного на конкретной стадии возобновления сознания формировало ядро их прогностического индекса возобновления, а динамика изменений во времени доклинически свидетельствовала о направление эволюции биоэлектрической активности головного мозга, а потому и эквивалентных пробковых фрункций. Все другие методы проведенной диагностики были вспомогательными и только усиливали или ослабляли вероятный прогноз.

Ключевые слова: количественная электроэнцесралограсрия; черепно-мозговая травма; посткоматозные нарушения сознания; нелинейный анализ ЭЭГ; атрактор; динамическая система; энтропия, детерминированный хаос; инсормационная размерность; прогностический индекс возобновления сознания. 